\title{
The Role of Finance on Achieving Companies Goals
}

\author{
Fatmir Mehmeti \\ Auditing Company "Etika" \\ fatmirmehmeti@yahoo.com
}

Pleurat Mustafa

Universiteti $A A B$

pleuratmustafa@hotmail.com

\begin{abstract}
The role of companies on economic development, in increasing employment and improving the welfare of its citizen by offering various products and services is continually increasing and having a higher significant role, especially in today's times of economic globalization that we have on. Different companies, whether privet or public have their own goals and objectives to achieve where their main goal is profit maximization. The basic element to achieve company's goal and objective is to ensure and manage financial funds. Business owners determent in the accomplished of objectives, including financial objectives, based on the high competition environment that is persistent and each time more aggressive, in order to survive and to achieve their foreseen goals, the company must continually make investments in (equipment, land, buildings, staff training, new staff engagement, marketing, etc. ), and in order to make these investments possible the company needs to achieve these financial tools, successful management of funds, where the auditing plays a significant role in the successful management. The financial system is undoubtedly a correct catalyst or better yet a laboratory where economic developments take the right shape and form. Complexity and size of organization makes it impossible for the higher management to control each individual if the organization is running its activity in the most effective way. Financial statements are a passport of companies where the management, accounting and auditors are highly linked. The aims of these financial statements are intended to provide reasonable assurance regarding the achievement of key objectives such as: Effectiveness and efficiency of operations, reliability of financial reporting and management, compliance with laws and regulations and preservation of assets. In this paper we will focus on the sources of financial funds of companies, successful management of finances as a basic element of meeting the objectives and internal and external audit as a key element that ensures the success of companies.
\end{abstract}

Keywords: Finance, Maximization of goals, Financial Management, Financial Statement, Investment, Effectively, Financial System, Auditing

\section{The role of finance in company}

The financial manager plays a dynamic role in a modern company's development. Today, external factors have an increasing impact on the financial manager. Heightened corporate competition, technological change, volatility in inflation and interest rates, worldwide economic uncertainty, fluctuating exchange rates, tax law changes, and ethical concerns over certain financial dealings must be dealt with almost daily. As a result, finance is required to play an ever more vital strategic role within the corporation. The financial manager has emerged as a team player in the overall effort of a company to create value. Thus today's financial manager must have the flexibility to adapt to the changing external environment if his or her firm is to survive.

The successful financial manager of tomorrow will need to supplement the traditional metrics of performance with new methods that encourage a greater role for uncertainty and multiple assumptions. These new methods will seek to value the flexibility inherent in initiatives - that is, the way in which taking one step offers you the option to stop or continue down one or more paths. In short, a correct decision may involve doing something today that in itself has small value, but gives you the option to do something of greater value in the future. 
Finance funds are very importatne in acheaving company's objectives. They are divedined in internal and external funds. Usually shareholders have high ambitions on acheaving their ideas, and the tendanancy is to investe in corrotaltion with sales or lunching a new product in order to fill the gape the markets needs, if the internal finance funds aren't enghouf, the need for external funds and additional funds is seen, whether that is through loan, donation, partnership ect. Therefore finance management plays a crucial role to sucsesfully manage the funds.

If you become a financial manager, your ability to adapt to change, raise funds, invest in assets, and manage wisely will affect the success of your firm and, ultimately, the overall economy as well. In an economy, efficient allocation of resources is vital to optimal growth in that economy; it is also vital to ensuring that individuals obtain satisfaction of their highest levels of personal wants. Thus, through efficiently acquiring, financing, and managing assets, the financial manager contributes to the firm and to the vitality and growth of the economy as a whole.

\section{What is financial management?}

Financial management is concerned with the acquisition, financing, and management of assets with some overall goal in mind. Thus the decision function of financial management can be broken down into three major areas: the investment, financing, and asset management decisions.

\section{Investment decision}

The investment decision is the most important of the firm's three major decisions when it comes to value creation. It begins with a determination of the total amount of assets needed to be held by the firm. Picture the firm's balance sheet in your mind for a moment. Imagine liabilities and owners' equity being listed on the right side of the balance sheet and its assets on the left. The financial manager needs to determine the dollar amount that appears above the double lines on the lefthand side of the balance sheet - that is, the size of the firm.

\section{Financial Decesion}

The second major decision of the firm is the financing decision. Here the financial manager is concerned with the makeup of the right-hand side of the balance sheet. Some firms have relatively large amounts of debt, whereas others are almost debt free.

In addition, dividend policy must be viewed as an integral part of the firm's financing decision. The dividend-payout ratio determines the amount of earnings that can be retained in the firm. Retaining a greater amount of current earnings in the firm means that fewer dollars will be available for current dividend payments. The value of the dividends paid to stockholders must therefore be balanced against the opportunity cost of retained earnings lost as a means of equity financing.

\section{The importance of the financial management in modern organizations}

If we were to take into consideration certain financial objectives, we might come up with ideas such as: survival; avoiding the financial crises or bankruptcy; overcoming competition; maximizing sales or market rate; minimizing costs; maximizing profits; maintaining an earnings' sustained growth.

Each of these possibilities shows problems that have to be solved by the financial management. If we take each mentioned idea, we might say that, at first sight, the company does not need a financial manager. For example, the sales' increase can be achieved by increasing the loan period offered to the clients. To minimize costs, the company can reduce the research volume of the research-development activity. Bankruptcy can be avoided very easily: we do not take loans or we do not take risks. But are these solutions really the best ones?

We do not borrow money, so we will not have debts and consequently the possibility that the company may go bankrupt because of the impossibility to return the funds does not exist anymore. Then, how will the company be able to finance its investments? Internal sources will never be sufficient enough, especially if the company decides to extend the loan period offered to clients. 


\section{As a conclusion, does the company actually need a financial manager?}

The answer id only one: obviously yes. The financial management plays a key part inside the company. The size and the importance of the financial management depend on the company's size. Inside small and medium-sized companies, the financial management's obligations are generally carried out by the accounting department. Once the company's size takes proportions, the importance of the financial management reflects in the establishment of certain distinct departments, directly subordinated to the company's president or the executive manager's by appointing a vice president of the finances, called financial manager.

Also, the financial management offers solutions for these major decisions of the company: the investment decision, the financing decision, and the dividend decision.

Assuming that the managers' objective is to maximize the company's value, the financial management has to find an optimal combination between the three major decisions. For example, the decision of investing in new assets supposes finding new financing sources. On the other hand, taking a financing decision influences, and is influenced by, the dividend decision because the retained incomes as internal financing sources would in fact belong to share-holders as dividends. The financial management's task is to analyze the effects of each decision and to find an optimal element to contribute to reaching the company's objective.

The financial management belongs to the company's decisional and control under-system, which processes and offers information both from the inside, as well as from the outside. Its basic concern is represented by the under-system's financial funds management, the success of this activity being vital for the company's survival.

The information received by the financial management refers to:

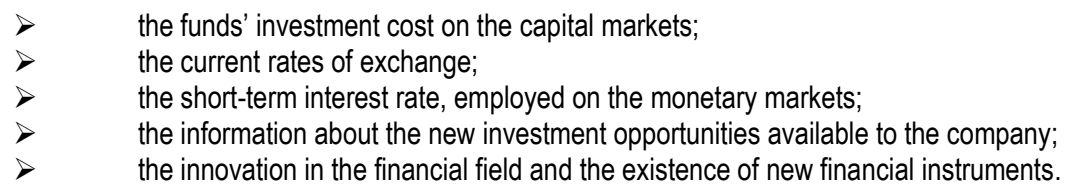

Regarding the decisional system, the financial management will give information about:

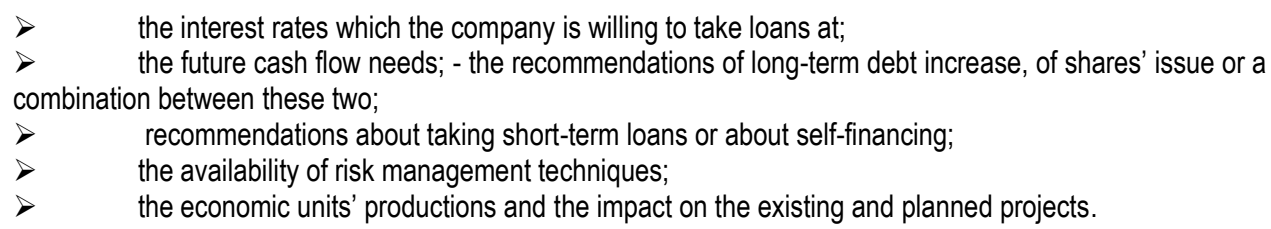

The financial dimension of a strategy is the one that better answers to the objectives of a company's shareholders: the company's market value maximization and the share's value maximization. Generally speaking, the basic purpose of the financial the basic purpose of the financial management's actions has to be company's survival and implicitly its situation's consolidation, demonstrated by getting some worthy market performances. For this reason, its role is to build a frame where the necessary connections between three fundamental variables are about to be established, namely: the company's objectives, the company's market value, the means and instruments used for measuring the company's financial and general performances.

Interferences and differences between the management of the accounting activity and the company's of the future financial management 
The finances represent the means and methods through funds are obtained, controlled, allotted and used. Accountancy is defined by the American Association of Accountancy as it follows: "the identification, evaluation and communication process of the economic information to allow the accomplishment of certain judgments and decisions by the users of that information"

The accounting activity has radically changed the content given by accountancy as a technique. Its purpose established centuries ago was to keep an evidence of the operations, of the incomes and expenses, to make the closing documents for an administration period. Nowadays, its basic purpose is to gather and analyze the information, contributing to the achievement of a competitive management, capable of capturing the future evolution of the economic activity. The risks faced by the company under the terms of a competitive economy make the information generated by qualitative accounting activity absolutely indispensable. Therefore, the accounting activity favours the effective and dynamic information process over the exploitation, financing and investment cycles developed inside the enterprise. Through the delivered data and information, it contributes to the increase of the economic efficiency, being able to determine the performed and employed expenses, the activity's due costs and their level inside the obtained incomes. Moreover, based on the accounting information managers can formulate the company's future strategy. However, it must be mentioned that these information can not be taken as such from the financial statements. They have to be thoroughly analyzed, from the point of view of the indicators that might be built, through the analysis of the external and internal environment, actually making an analysis of the strategic resources of the company.

Therefore, we consider that the accounting activity becomes the support of the financial management's accomplishment in any economic entity. The purpose of the financial activity is to offer the enterprise the financial and technical resources necessary to its functioning and development. The financial activity's practice is never entirely delegated and it stays in a close accounting activity dependency, but it also depends on the general management. Basically, the accountancy evaluates the financial transactions, while the finances manage the financial transactions and the company's basic financial position. Frequently, it has been considered that making reference to the accounting information in the financial statements for the financial analysis and prediction makes the financial management to become an "appendage" of the accounting activity. The vision has seized to exist when the financial management got specialized, even occupying a privileged place in the company's administration.

The investments' opportunity, the surveillance of performance indicators, the budgetary balance in case of unpredicted events, are considered obligations of the financial activity and of the financial management because all financing plans, income and expenses budget, the treasury budget are its scope. But these obligations can not be accomplished but on the information provided by the financial statements elaborated inside the accounting activity.

Although the accounting activity and the financial one might be considered as different functions, they are closely related. In many situations, it is impossible for managers to establish certain tasks just for the financial department. For example, when a before-calculation of the price is required, which is considered an obligation of the financial activity, will also require information about the costs, generated by the managerial accountancy. The interference between the two activities is therefore inevitable.

There are however two basic differences between the financial management and the accounting activity:

The funds' recognition method. The first objective of the accounting activity is to change and deliver information necessary to the measurement of the company's performances, declaring the financial status. Using some generally accepted and regulated standards and principles, the accountants prepare the financial statements that establish the profit or the incomes based only on the registered sales and expenses. On the other hand, the financial manager focuses on the entries and issues of cash flow. He keeps the company's solvency by analyzing and planning the cash flows necessary for paying the obligations and purchasing the assets needed by the company to reach its objectives. The financial manager uses the cash-flow method in order to acknowledge the incomes and expenses, being interested only in the cashflow entries and issues. 
The decisional process. If the ones involved in the accounting activity focus on collecting the information and showing the financial statements, the financial manager evaluates the situations elaborated by the accounting activity, creates additional information and takes decisions based on following analyses. The purpose of the financial activity is to provide correct and easilyinterpretable information about the company's past, present and future operations. The financial manager uses this information, either in their initial shape, or after certain processing and analyses, as important entries for the decisional process. Certainly, this does not mean that the personnel which contributes to the accounting activity's development does not take decisions or that the financial manager does not gather information, but it supposes that 599 the accounting and the financial management focus on certain different objectives.

\section{Objectives}

Unfortunately, most of the managers only study the financial statements when they want to value the company's performance. For example, the accounting balance reflects the assets at their accounting balance reflect the assets at their accounting value. He does not take into consideration their value on the market and does not offer any information about the success of the investments.

A series of researches demonstrated that the role of those with financial or legal training, from the management's superior and the inferior echelons as well, has become more and more important. Therefore, it is more and more important that the employees in the accounting, marketing, production, personnel and other departments to understand the financial field in order to be good professionals in their own departments. For example, accountants should understand the way in which information, delivered by them through the financial statements and other similar reports, is analyzed by investors. The accounting activity's function is to provide the quantitative financial information so that it can be used when taking economic decisions, while the financial management has as basic tasks to plan, to provide, to assign and to use the financial funds, so that the economic entity's value and efficiency to be maximal.

\section{The role and function of external auditors}

Financial statements are used for a variety of purposes and decisions. For example, financial statements are used by owners to evaluate management's stewardship, by investors for making decisions about whether to buy or sell securities, by credit rating services for making decisions about credit worthiness of entities, and by bankers for making decisions about whether to lend money. Effective use of financial statements requires that the reader understand the roles of those responsible for preparing and auditing financial statements.

Financial statements are the representations of management. When using management's statements, the reader must recognize that the preparation of these statements requires management to make significant accounting estimates and judgments, as well as to determine from among several alternative accounting principles and methods those that are most appropriate within the framework of generally accepted accounting standards.

In contrast, the auditor's responsibility is to express an opinion on whether management has fairly presented the information in the financial statements. In an audit, the financial statements are evaluated by the auditor, who is objective and knowledgeable about auditing, accounting, and financial reporting matters.

During the audit, the auditor collects evidence to obtain reasonable assurance that the amounts and disclosures in the financial statements are free of material misstatement. However, the characteristics of evaluating evidence on a test basis, the fact that accounting estimates are inherently imprecise, and the difficulties associated with detecting misstatements hidden by collusion and careful forgery, prevent the auditor from finding every error or irregularity that may affect a user's decision. The auditor also evaluates whether audit evidence raises doubt about the ability of the client to continue as a going concern in the foreseeable future. However, readers should recognize that future business performance is uncertain, and an auditor cannot guarantee business success.

Through the audit process, the auditor adds credibility to management's financial statements, which allows owners, investors, bankers, and other creditors to use them with greater confidence. The auditor expresses his assurance on the financial statements in an auditor's report. The report, which contains standard words and phrases that have a specific 
meaning, conveys the auditor's opinion related to whether the financial statements fairly present the entity's financial position and results of operations. If the auditor has reservations about amounts or disclosures in the statements, he modifies the report to describe the reservations. The auditor's report and management's financial statements are only useful to those who make the effort to understand them.

\section{The Financial Statement Audit}

The objective of the financial statement audit is to add credibility to management's financial statements. Access to capital markets, mergers, acquisitions, and investments in an entity depends not only on the information that management provides in financial statements, but also on the degree of assurance that the financial statements are free of material error and fraud. In the process of providing reasonable assurance that financial statements are fairly presented, an auditor assesses whether:

Transactions and amounts that should have been recorded are reported in the financial statements.

The assets and liabilities reported in the financial statements existed at the balance sheet date, and the transactions reported in the financial statements occurred during the period covered by the statements.

Reported assets are owned by the entity and liabilities owed by the entity at the balance sheet date are reported.

The financial statement amounts (assets, liabilities, revenues, and expenses) are appropriately valued in conformity with accounting standards.

The financial statement amounts are properly classified, described, and disclosed in conformity with accounting standards.

The independent auditor forms an opinion on the overall fairness of the financial statements by testing the above representations. The opinion is communicated in the auditor's report. The standard auditor's report contains an unqualified opinion, which means that an auditor believes, without reservation, that tie financial statements present fairly the entity's financial position and results of operations in conformity with accounting standards. A qualified report, in contrast, notifies financial statement readers about concerns the auditor has about matters affecting the financial statements (such as the selection of accounting policies or the method of their application or the adequacy of financial statement disclosure) or about limitations in the scope of the auditor's work. Therefore, a user should understand the implications of a qualified opinion and read this type of report carefully.

Therefore we can easely say that an internal and external audit plays a very important role for showing a real state of company to its owners for evoiding risks during decision taking process, expecialy while investing which are oriented on increasing product quality and services, as e tool of acheaving forseen objective

\section{Responsibility for Financial}

Statements Effective use of financial statements requires that the reader understand the roles of those responsible for preparing, auditing, and using financial statements. Management is responsible for the content of its financial statements, regardless of an organization's size or form of ownership. The preparation of these statements requires management to make significant judgments and estimates. Management's responsibility for financial statements is not lessened by having the statements audited.

\section{The Independent Audit}

An audit allows creditors, bankers, investors, and others to use financial statements with confidence. While the audit does not guarantee financial statement accuracy, it provides users with a reasonable assurance that an entity's financial statements give a true and fair view (or "present fairly") its financial position, results of operations, and changes in financial position in conformity with accounting standards. An audit enhances users' confidence that financial statements do not 
contain material error and fraud because the auditor is an independent, objective professional who is knowledgeable of the entity's business and financial reporting requirements.

\section{Using Financial Statements}

The auditor's report and financial statements presented by management are useful only to those who make the effort to understand them. Effective use of audited financial statements also requires a basic understanding of accounting standards, the related concepts of financial measurement and disclosure, and the inherent limitations of financial statements caused by the use of accounting estimates, judgments, and various alternative accounting principles and methods.

\section{Safety and Financial Statements}

The purpose of the audit is to enable the auditor to express an audit opinion on whether the financial information gives a true and fair view (or is "fairly presented") in accordance with the basis of accounting indicated. Auditors perform procedures designed to obtain reasonable assurance regarding the reliability of management's representations in the financial statements.

Guidelines established by the International Committee of the Auditing Practices recognize three types of services that an accountant can provide financial statements: an audit, a review, and a compilation. Each type of service provides a different level of security, in connection with the presentation of financial statements and disclosures.

\section{Financial Statement Audits}

An audit provides a high degree of security for users. The independent auditor's tests of basic data entity's financial statements to obtain evidence that, along with its other procedures, provides the basis for our audit opinion on whether the financial statements are free from material misstatement or fraud (that is, Irregularities).

In an audit of financial statements, the auditor forms a general conclusion about whether -

- financial information has been prepared using appropriate accounting standards, which are applied consistently;

- The financial information in accordance with the statute or the relevant laws;

- The view presented financial information is entirely consistent with business knowledge auditor of the entity;

- There is adequate disclosure of all material matters relevant to the proper presentation of financial information.

\section{Conclusions}

Knowledge through financial management will not restrict only to numerical data. For a complete image of the cause and effect type of relations, it is necessary to combine the structured information - data - with the non-structured information text.

Consequently, in a society of latest generation information technology knowledge, a Web environment at the level of the whole company allows the interaction, the distribution of results and achievement of the organization's personality.

The financial management offers the possibility to plan the "way" to achieve the proposed objectives, to cover a well-defined path and to take advantage of the new opportunities which come along.

At the same time, it offers an image of the compatibility between the company's internal processes, the existing financial sources, their cost and way of appropriation, offering strategic recommendations to avoid unpleasant events that may occur. 
The most decisive matter regarding the financial management is represented by the managing team's level of involvement into the necessary changes. Without a strong involvement, the financial management can not be implemented.

\section{Recommendations :}

$>$ Effective management of finance affects company performance

$>$ The effect of auditing on accountability and increasing of efficiency on management of finance

$>$ The function of audit system on companies to have effective control

Auditing ensures a high security for users resulting for a fair presentation of financial statement

\section{Bibliography}

Dr. Sc. Pleurat Mustafa, lectures by subject Global entrepreneurship and innovation, AAB University, 2014

Dr. Sc. Pleurat Mustafa, lectures by subject Project Management, AAB University, 2014

Mustafa, I. (2008), Menaxhmenti Financiar, botimi i tretë, Prishtine: Riinvest

Muhamet Mustafa: Menaxhimi i Investimeve, Prishtinë, 2009

http: //www. prenhall. com/divisions/bp/app/chapters/vanhorne12. OLDArchive032207/chap01. pdf http: //fse. tibiscus. ro/anale/Lucrari2009/100. \%20Ciuhureanu. pdf

file: //C: /Users/Admin/Downloads/The\%20role\%20and\%20function\%20of\%20external\%20auditors\%20 (1). pdf Principles of External Auditing by Porter, Brenda (Author) Somerset, NJ, USA: John Wiley , 2003.

Financial Accounting and Reporting 11th Edition Barry Elliott and Jamie Elliott 